\title{
OBSERVATIONS ON AN APPARENT POPULATION EXTENSION OF GLOSSINA TACHINOIDES WESTWOOD IN SOUTHERN IVORY COAST
}

\author{
F. A. S. Kuzoe*, D. A. T. Baldry $\dagger$, A. van der Vloedt $\ddagger$ and J. R. Cullen $§$ \\ *Trypanosomiases and Leishmaniasis Unit, Division of Parasitic Diseases, World Health Organization, \\ Avenue Appia, Geneva, Switzerland, †WHO Onchocerciasis Control Programme, B.P. 549, \\ Ouagadougou, Upper Volta, ‡International Atomic Energy Agency, Vienna, Austria and $\$ 2$ Church \\ Street, Ewell Village, Epsom, Surrey, U.K.
}

(Received 24 October 1983; revised 3 May 1984)

\begin{abstract}
Recent entomological surveys in the Bouafle sleeping sickness focus of the Ivory Coast have revealed that Glossina tachinoides is considerably more widely distributed than hitherto. Some flies were found in the fringing riverine forests of tributaries of the River Marahoué. However, the greatest concentrations were found in villages and settlements where domestic pigs were kept. The southern limit of $G$. tachinoides now appears to lie one half degree of latitude further south than that reported by earlier investigators. The authors think there is good evidence that $G$. tachinoides is extending its range eastwards and southwards through and beyond the Bouafle area, and the epidemiological significance of this is briefly discussed.
\end{abstract}

Key Words: Glossina tachinoides, distribution, extension, peridomestic, vector, human trypanosomiasis, Ivory Coast

\begin{abstract}
Résumé-Des enquêtes entomologiques récemment effectuées dans le foyer de maladie du sommeil de Bouaflé en Côte d'Ivoire ont révélé que Glossina tachinoides a une distribution beaucoup plus large que dans le passé. Certaines mouches se recontrent dans les forêts riveraines bordant les tributaires de la rivière Marahoué. Les concentrations les plus fortes sont cependant observeés dans les villages et les colonies de peuplement où se pratique l'élevage des porcs. La limite sud de répartition de $G$. tachinoides semble se situer à l'heure actuelle à 0,50 degré de latitude plus au sud qu'il n'a été signalé auparavant par d'autres chercheurs. Pour les auteurs, tout laisse croire que l'aire de répartition de $G$. tachinoides s'étend vers l'est et le sud, traversant la région de Bouaflé. L'importance épidémiologique de cette extension est brièvement discutée.
\end{abstract}

\section{INTRODUCTION}

From an appraisal of the distribution of Glossina tachinoides Westwood in southern Nigeria, Baldry $(1966 \mathrm{a}, \mathrm{b})$ predicted that as more of the West African rain forest belt was opened up, peridomestic populations of this species would extend further southwards both in Nigeria and in countries further west. At the time of his study Baldry (1966b) thought that the southern limit of $G$. tachinoides in the Ivory Coast was slightly south of latitude $9^{\circ} 00^{\prime}$ north.

According to the OAU/STRC tsetse distribution maps prepared by Ford and Katondo (1977), by 1973 $G$. tachinoides was distributed in the central Ivory Coast as far south as $7^{\circ} 30^{\prime}$ north. Subsequently, a low density population of $G$. tachinoides was detected in the fringing forests of the River Marahoue (Bandama Rouge) adjacent to Bouaflé town at latitude $7^{\circ} 00^{\prime}$ north and longitude $5^{\circ} 45^{\prime}$ west (Laveissière and Challier, 1976).

During late 1978 and early 1979, tsetse surveys in the Bouaflé sleeping sickness focus by these authors revealed the presence of $G$. tachinoides in an additional nine localities. This paper describes and discusses new $G$. tachinoides distribution records for the Bouaflé area.

\section{DESCRIPTION OF THE BOUAFLE AREA}

\section{General geographic features}

Bouafié town is situated at latitude $7^{\circ} 00^{\prime}$ north and longitude $5^{\circ} 45^{\prime}$ west, on the east bank of the River Marahoué between Daloa and Yamoussoukro, and some $324 \mathrm{~km}$ north of Abidjan.

Bouaflé is at an altitude of $160 \mathrm{~m}$ a.m.s.l. (above mean sea level), but much of the $700-800 \mathrm{~km}^{2}$ surrounding countryside which embraces the sleeping sickness focus is at $200 \mathrm{~m}$. Higher ground is found to the south where some hills rise to more than $300 \mathrm{~m}$, and to the east where there is an upland complex with some hills rising above $600 \mathrm{~m}$.

The area is bissected in a north-west to south-east direction by the valley of the River Marahoue. In the north of the area the river bed is at an altitude of slightly over $160 \mathrm{~m}$, while to the south it is slightly less than $160 \mathrm{~m}$.

Human populations of the area belong mainly to the Mande-Gouro and the Mande-Baoule ethno-cultural groups. In addition there are many immigrant labourers and farmers from Upper Volta.

\section{Climate}

Because of its proximity to the coastal rain forest 
belt, the area is generally wet and humid. Mean monthly rainfall varies between 19.4 and $220.9 \mathrm{~mm}$, and the mean number of wet days per month from 1.3 to 13.8. Mean monthly maximum temperatures vary from 29 to $35^{\circ} \mathrm{C}$ and mean monthly minimum temperatures from 21 to $22^{\circ} \mathrm{C}$.

During the dry season months of November to February, winds are generally northern in direction. At other times, they are from the south and southwest.

\section{Vegetation}

That part of the Bouafle area in which the survey was carried out is surrounded to the south and west by dense, humid, semi-deciduous, mesophilic rain forest. The most distinctive tree species of this area are Celtis sp., Triplochiton scleroxylon, Aubrevillea kerstinglii and Khaya grandifoliola. Some of these trees attained heights of up to $50 \mathrm{~m}$. Other large forest trees found in some places were Ceiba pentandra and Terminalia superba (up to $50 \mathrm{~m}$ ) and Bombax sp. (up to $40 \mathrm{~m}$ ).

North of the forest in the central Bouaflé sleeping sickness focus area the following types of vegetation were encountered:

(1) Forest islands and riverine forests. Many of the forest islands and riverine forests were little influenced by man and therefore had the same basic character as the true rain forest. Others had been degraded to make way for villages, plantations, farms and roads. In most places where human influence was small, the forests had a multistorey structure. The upper indigenous layer was composed of tall emergent trees, whose compact crowns frequently provided a closed canopy. The lower indigenous layers were composed of low forest and/or thickets attaining heights of 10 to $15 \mathrm{~m}$.

Forest edges were usually marked by dense thickets or dense stands of the grass Imperata cylindrica. More precise details of the distribution of the forest islands can be obtained from the "Carte reguliere de l'Afrique de l'Ouest à 1/200000-République de Côte d'Ivoire, Feuilles NB-30-XIX (Bouaké) et NB-30XIII (Gagnoa)" and from Guillaumet, and Adjanohoun (1971).

In many places much of the lower indigenous forest layers had been reduced or destroyed to make room for plantations. The commonest plantation trees were coffee (Coffea indico) and cocoa (Throbroma cacao), but there were also many plantations of banana/ plantain (Musa sapientum), mango (Mangifera indica), teak (Tectona) and neem (Azadirachta indica).

(2) Savanna. Forest islands and riverine forests were generally separated by areas of relatively open savanna, particularly to the north of Bouaflé. The commonest savanna trees and shrubs were, Anona senegalensis, Borassus aethiopum, Cochlospermum planchoni, Cussonia barteri, Lophira lanceolata, Piliostigma thonningii and Terminalia glaucescens. Species of Hyparrhenia, Loudetia, Panicum and Sporobolus were the commonest grasses.

(3) Village vegetation. Villages were usually compact and often devoid of trees and shrubs, except around their perimeters. In addition to the occasional tall forest tree, trees and shrubs found in some villages included, Cassia sp., neem, teak, mango, citrus (Citrus medica), banana, plantain, oil palm (Elaeis guineensis), coconut palm (Cocos nucifera),

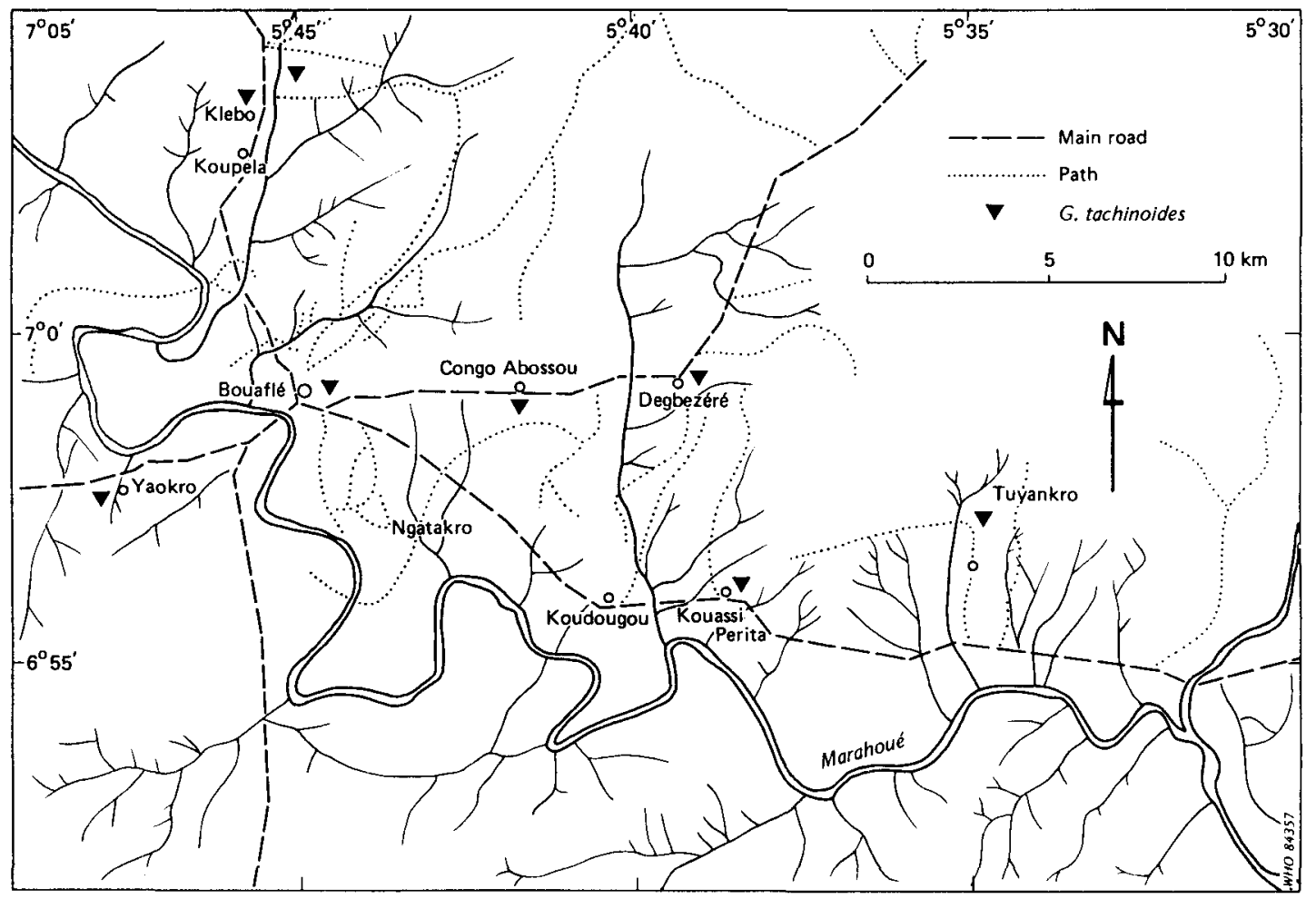

Fig. 1. Showing the locations of the places where G. tachinoides was captured in the Bouafle area. 
Table 1. Density of $G$. tachinoides populations in the Bouafle area 1978/79

Mean number of flies/trap per day*

\begin{tabular}{lccc}
\multicolumn{1}{c}{ Locality } & Males & Females & Both sexes \\
\hline Tributaries near Klebo & 2.0 & 6.0 & 8.0 \\
Klebo Village & 3.5 & 4.2 & 7.7 \\
Congo-Aboisso Village & 7.0 & 1.0 & 8.0 \\
Degbezére Village & 17.3 & 14.7 & 32.0 \\
Yaokro Village & 0.8 & 0.9 & 1.7 \\
Bouaflé Town & 0.0 & 1.0 & 1.0 \\
Kouassi-Perita Village & 1.0 & 0.0 & 1.0 \\
Tuyankro Village & 0.0 & 0.5 & 0.5 \\
\hline
\end{tabular}

*Using Challier and Laveissière biconical traps.

castor oil (Ricinus sp.), aubergine (Solanum melongena), kola (Cola nitida), Jatropha curcas, Lantana camara and $P$. thonningii. The principal crops were yam (Dioscorea alata and $D$. rotenda), rice (Oryza sp.) and maize (Zea mais). Crops of secondary importance included cassava (Manihot utilissima), groundnuts (Apios tuberosa), cotton (Gossypium sp.), pineapple (Ananas sp.) and tobacco (Nicotiana tabacum).

\section{RESULTS AND DISCUSSION}

The localities from where $G$. tachinoides were collected in the Bouafle area are shown in Fig. 1, while an indication of population density are presented in Table 1.

The only flies found in riverine situations were those collected along tributaries of the River Marahoué approx. $3 \mathrm{~km}$ east of Klebo village, and a few hundred metres south-west of it. In all other cases flies were peridomestic in settlements where domestic pigs were kept.

Flies were generally more numerous to the north and north-east of Bouaflé town, i.e. north of latitude $7^{\circ} 00^{\prime}$ north, than to the south and south-east, suggesting that the northern populations were older and better established than the others. The absence of $G$. tachinoides in the southern part of the Bouafle area and further east towards Yamoussoukro suggests that the zone immediately south and south-east of Bouaflé town was being infiltrated by flies from established populations to the north of the town. It thus appears to the writers that at the time of their surveys, $G$. tachinoides was in the process of a slow but steady advance through the Bouafle area from the north to the south and east. This apparent advance has possibly been initiated or facilitated by a southwestward extension of the western edge of Lake Kossou (formerly the River Bandama Blanc) located to the north-east of and forming the boundary of, the Bouaflé area. (N.B. The shortest distance between Bouafle town and the edge of Lake Kossou is now only $15 \mathrm{~km}$.) Flooding of the west-bank tributaries of

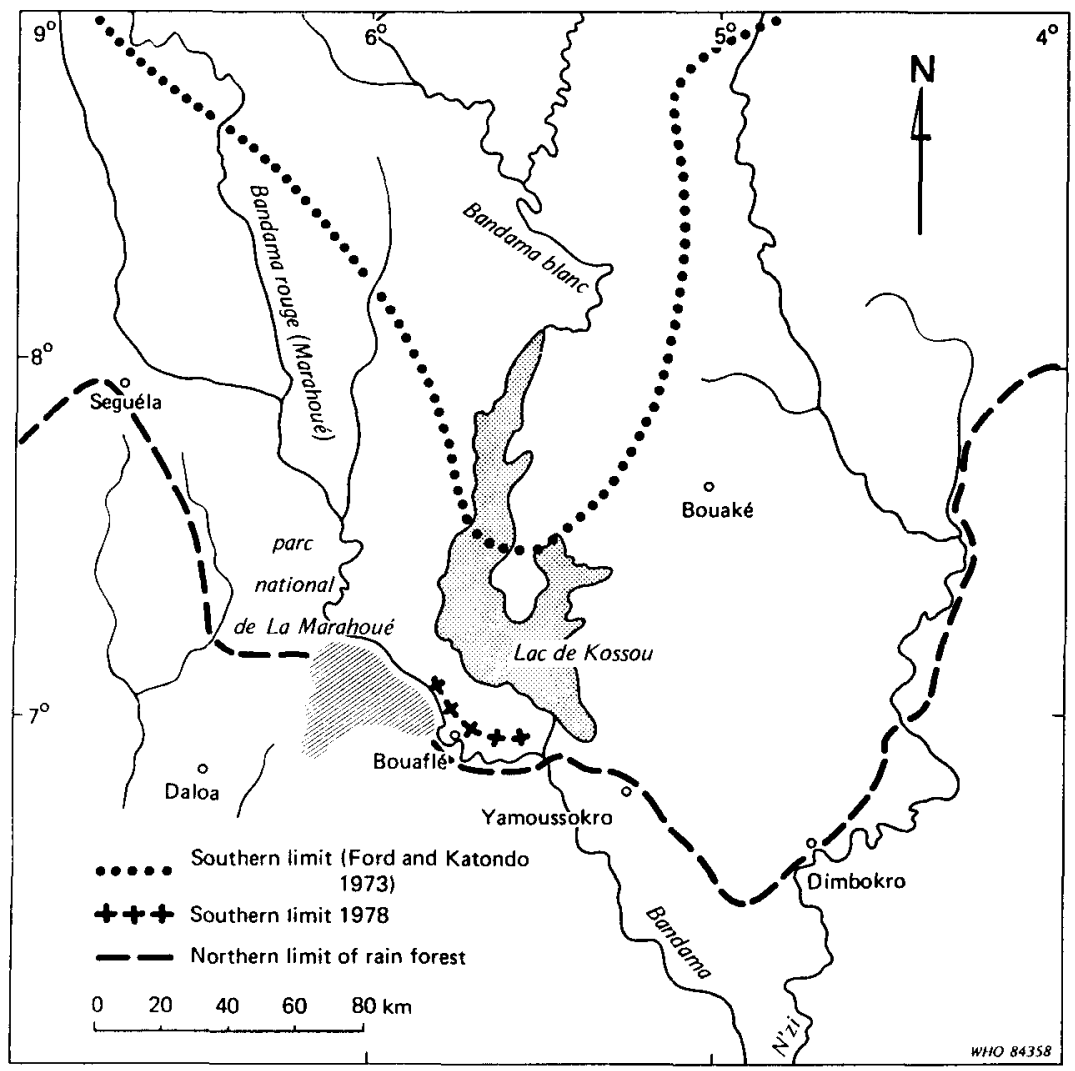

Fig. 2. Part of central Ivory Coast showing the northern edge of the rain forest belt and the southern limits of G. tachinoides according to Ford and Katondo (1977) and according to the information presented in this paper. 
the River Bandama Blanc, as the water level of Lake Kossou rose, probably forced $G$. tachinoides across the watershed into the east-bank tributaries of the River Marahoué, from which adaptation to the peridomestic situation enabled it to disperse southwards around the western edge of the newly created suitable habitats.

Detailed tsetse surveys in the Bouafle sleeping sickness focus have revealed that $G$. tachinoides is distributed through an area of approx. $220 \mathrm{~km}^{2}$, with the southern and eastern limits of the infestation at latitude $6^{\circ} 55^{\prime}$ north and longitude $5^{\circ} 37^{\prime}$ west, respectively. Thus at this longitude the apparent present southern limit of this species is more than one half degree of latitude [equivalent to approx. $52 \mathrm{~km}$ further south that reported by Ford and Katondo (1977)]

Although some small riverine populations of $G$. tachinoides were observed in the north of the Bouaflé area, most of the populations were characterized by being peridomestic and closely associated with local domestic pigs. The species was never found in rainforest, in forest islands or in the fringing forests of the River Marahoué and its larger tributaries, presumably because the vegetation was too dense near ground level and because acceptable hosts were too scarce. The situation was therefore almost identical to that described for southern Nigeria by Baldry (1969, and earlier papers).

The impression gained was that the filling up of Lake Kossou to the east had exerted pressure on $G$. tachinoides in the former River Bandama Blanc valley to cross the watershed into the catchment area of the River Marahoué, through which it appeared to be extending to the south and east, down the western edge of the Baoule $\mathrm{V}$ forest/savanna zone.

As the Baoule $V$ is heavily populated and as domestic pig populations are numerous and widely distributed, it seems likely that $G$. tachinoides from the environs of Bouaflé town will soon occupy all forest/savanna areas along the western edge of the Baoule $\mathrm{V}$ between Lake Kossou and the rain forest belt. From these areas, it would be only a matter of time before the species was able to extend southwards into the Gagnoa forest/savanna belt and southeastwards into the southern tip of the Baoule V.

It is also worthy of mention that $G$. tachinoides may also be extending southwards along the eastern edge of the Baoule $\mathrm{V}$ from areas to the east of Bouaké town. In 1977, G. tachinoides was found along the River Nzi east of Bouaké at latitude $7^{\circ} 46^{\prime}$ north and longitude $4^{\circ} 40^{\prime}$ west (Dr P. van Wettre, personal communication); $125 \mathrm{~km}$ further south than the southern limit of the species at that longitude according to the map of Ford and Katondo (1977, Fig. 2). In 1978 the present writers also surveyed a number of areas south of Bouake in the Baoule $\mathrm{V}$, but were unable to detect $G$. tachinoides. However, it was very evident that, in all the areas visited, ideal conditions existed for entry and establishments of pig-feeding, peridomestic $G$. tachinoides populations.

The writer's conclusion is that a southward extension of $G$. tachinoides into the Baoule $\mathrm{V}$ is now well advanced, and that in time the whole of this area will become infested. As $G$. tachinoides is an efficient vector of both human and animal trypanosomes, it is to be expected that, in the near future, there may be some significant changes in the epidemiological patterns of human and animal trypanosomiasis in areas invaded by this species.

Acknowledgements --We are grateful to the field staff of Applied Research Project on African trypanosomiasis, Bouaflé, who assisted in the surveys. This project received financial support from the UNDP/World Bank/WHO Special Programme for Research and Training in Tropical Diseases.

\section{REFERENCES}

Baldry D. A. T. (1966a) On the distribution of Glossina tachinoides in West Africa. I: The distribution of $G$. tachinoides in southern Nigeria. Rep. Ilth Mtg int. sci. Coun. Tryp. Res. Nairobi 1966, CCTA Publication No. 100, pp. 95-102.

Baldry D. A. T. (1966b) Idem. II: An assessment of the probable present distribution of $G$. tachinoides in West Africa and of possible future extensions, based on existing records and recent observations in southern Nigeria. Ibid. pp. 103-109.

Baldry D. A. T. (1969) Variations in the ecology of Glossina spp. with special reference to Nigerian populations of Glossina tachnoides. Bull. Wld Hlth Org. 40, 859 869.

Ford J. and Katondo K. M. (1977) Maps of tsetse fly (Glossina) distribution in Africa, 1973 according to subgeneric groups on scale of $1: 5,000,000$. Bull. Anim. Hlth Prod. 25, 187-198.

Guillaumet J. L. and Adjanohoun E. (1971) Carte de la végétation de la Côte d'Ivoire à l'echelle de 1/500,000. Mem. ORSTOM No. 50, Le Milieu Naturel de la Côte d'Ivoire, ORSTOM, Bondy, France.

Laveissiere C. and Challier A. (1976) Le foyer de Trypanosomiase Humaine de Bouaflé (Côte d'Ivoire): Enquête Entomologique et Epidémiologique, Propositions pour une Campagne Insecticide. Doc. Techn. OCCGE, No. 6308. 